\title{
ANALYSIS OF THE DEPENDENCE BETWEEN JUMPING TAKEOFF AND ANTHROPOMETRIC INDICATORS OF FEMALE FIGURE SKATERS
}

\author{
Tatiana Yordanova \\ National Sports Academy “Vassil Levski”, Sofia, Bulgaria
}

ORCID (1D

Tatiana Yordanova https://orcid.org/0000-0002-7750-5774

\begin{abstract}
Jump Elements in figure skating are an integral part of motor activity. One of the conditions for their good performance is great height and length. Criteria for this are the indicators of speed and power qualities.

The aim of this research work is to analyze the relationship between anthropometric indicators and those for jumping takeoff of young female figure skaters of the basic level of training. Seventeen female skaters aged 10-14 years old (prepuberty) from ice skating clubs in Bulgaria voluntarily participated in the study. The age of the participants was 10 to 14 years old, which is considered favorable for the development of speed and strength abilities. They were subjected twice to 8 anthropometric measurements and 5 different types of takeoff, conducted in off-ice conditions. To achieve the goal of the survey, the following research methods were used: theoretical analysis and generalization of data in specialized scientific and methodological literature, pedagogical observation, pedagogical testing, anthropometric research methods and methods of mathematical statistics for processing the results of the study.

The results showed significant intragroup dependences for the anthropometric and biomechanical parameters for all types of jumps takeoff in the first study and a decrease in the correlation coefficients in the second measurement. The maximum force in all types of jumps increases with increasing indicators of height, weight, length of the lower limbs, chest circumference, shoulder width, while the width of the pelvis does not affect the strength of the takeoff. The height of the jumps with the help of the arms depends on the width of the shoulders $-r=.497$, and for vertical jump with the hands on the hips $-r=.664$.
\end{abstract}

Key words: figure skating, anthropometric indicators, speed-force parameters.

\section{INTRODUCTION}

Modern figure skating has reached a very high level of technical mastery. Victory in high-ranking competitions is achieved only by athletes whose arsenal includes the most technically complex elements of figure skating. Achieving the desired result is possible only if you demonstrate these elements during the competition.
The main trends in the development of programs in the individual disciplines of figure skating are the complexity of the jumps, their combinations and series, the aspiration of the skaters to diversity, balance and artistic design (Lysova, 1997). Jumping takes a leading place in the programs of every highly qualified figure skater, because they have the greatest impact on the final result in competitions. 
Nowadays, skaters learn the most complex jumping elements in adolescence. Only 15-20 years ago, in top-level competitions, the triple Axel and quadruple jumps were performed only by the top five best skaters in the world. Nowadays we are witnessing the performance of quadruple jumps not only by men but also by women. In order to achieve high results when performing multi-turn jumps, the modern training process must be aimed at improving their quality and increasing the amount of revolutions performed during the flight. This can be achieved by increasing the height and length of the jump, as well as the initial angular velocity of the bounce, followed by the rapid grouping of body parts in flight. All this, above all, requires a high level of development of speed and power qualities.

Figure skating is a sport that combines endurance, strength, flexibility and grace with a touch of artistry. The high level of discipline forces more and more young athletes to train outside the standards considered safe for a young, growing body (Porter, Young, Niedfeldt, Gottschlich, 2007). As it is one of the early specialized sports (American Academy of Pediatrics (AAP), 2000); monitoring training effects and physical development, performing and evaluating anthropometric measurements and physical fitness tests regularly in and out of group comparisons can be useful for monitoring performance.

Physical morphology or physique, including body mass or composition, size and shape, is important to optimize athletic performance in many sports (Slater, O'Connor, \& Kerr, 2018; Durakovic, 2012). The results of some studies suggest that figure skating favors lightness, leanness, higher mesomorphy and lower endomorphy at more elite levels (Monsma, \& Malina, 2005). Mesomorphic type of the figure is characterized by proportional body size and harmonious development of the musculoskeletal system. The higher degree of mesomorphy is associated with good physical capacity and greater development of the explosive force of the lower extremities (Toteva, 1992). The study of Paluchowska M. (2015) found that female figure skaters are relatively shorter and lighter than their non-sports peers, which suggests a greater influence of sports-training factor on growth than genetic factors. The lower the athlete's weight, the less energy he or she has to put into performing certain elements (such as jumping). However, it is known that athletes with relatively low body weight and height have better results in figure skating. Elite sporting performance is the result of the interaction between genetic and training factors, with the result that both talent identification and management systems to facilitate optimal training are crucial to sporting success (Tucker, \& Collins, 2012).

The goal of the study is to analyze the relationship between anthropometric indicators and those of the jumping takeoff of skaters.

\section{MATERIALS AND METHOD}

To achieve the goal of the study, we set the following tasks to solve:

- Measurement of anthropometric indicators of the skaters.

- Measurement of speed and power indicators with BTS G-sensor equipment.

- Calculation of body mass index.

- Establishing a correlation between anthropometric parameters and those for jumping abilities (takeoff).

The subject of the study is the dialectical relationship between parameters of the anthropometric features and speed-strength readiness in the jump elements by the young figure skaters.

The object of the research are the measurements of the anthropometric factors and speed-power indicators of the skaters.

The following research methods were 
used to solve the set tasks:

- Analysis and summarization of the scientific literature.

- Pedagogical supervision.

- Sports-pedagogical testing: anthropometric medical measurements; instrumental methods.

- Math statistical methods.

\section{Participants}

Seventeen figure skaters with a basic level of preparation aged 10 to 14 (before puberty) from Ice Skating Clubs in the Republic of Bulgaria voluntarily participated in the study. All participants are competitive figure skaters who annually participate at National Championships and International tournaments from the
ISU calendar in single categories from Basic Novice to Juniors. All of them can execute all double jumps (except double Axel).

\section{Organization of the research}

To solve the tasks, research was organized and conducted between 2015 to 2017 in the Center for Research and Applied Activity in Sports, in the Department of "Anatomy and biomechanics" of the National Sports Academy "Vassil Levski" and in the Winter Sports Palace.

To obtain current and cumulative information about the latent state and dynamics of development of the individual signs and components of the studied subjects' motor abilities, we used a test battery (Table 1).

Table 1. Measured parameters

\begin{tabular}{|c|c|c|c|}
\hline № & Measured parameters & Measure units & Measurement accuracy \\
\hline \multicolumn{4}{|c|}{ Anthropometric indicators } \\
\hline 1 & Body height & {$[\mathrm{cm}]$} & 0.1 \\
\hline 2 & Body weight & {$[\mathrm{kg}]$} & 0.1 \\
\hline 3 & Chest Volume & {$[\mathrm{cm}]$} & 0.1 \\
\hline 4,5 & Length of right and left lower limbs & {$[\mathrm{cm}]$} & 0.1 \\
\hline 6,7 & Shoulder width, pelvis width & {$[\mathrm{cm}]$} & 0.5 \\
\hline 8 & Foot length & {$[\mathrm{cm}]$} & 0.5 \\
\hline \multicolumn{4}{|c|}{ Biomechanics indicators } \\
\hline 9 & Squat Jump & {$[\mathrm{cm}, \mathrm{kN}, \mathrm{m} / \mathrm{s}]$} & 0.01 \\
\hline 10 & Counter Movement Jump & {$[\mathrm{cm}, \mathrm{kN}, \mathrm{m} / \mathrm{s}]$} & 0.01 \\
\hline 11 & Counter Movement Jump with arms rush & {$[\mathrm{cm}, \mathrm{kN}, \mathrm{m} / \mathrm{s}]$} & 0.01 \\
\hline 12 & Drop jump & {$[\mathrm{cm}, \mathrm{kN}, \mathrm{m} / \mathrm{s}]$} & 0.01 \\
\hline 13 & 20 repeated jumps & {$[\mathrm{cm}, \mathrm{kN}, \mathrm{m} / \mathrm{s}]$} & 0.01 \\
\hline
\end{tabular}

The measurements were conducted twice: July 2015 and August 2017. Participants were wearing light clothing and no shoes during measurements. To study the peculiarities of the physical development of young skaters and analyze the relationships between the individual characteristics of body structure and athletic success, we conducted anthropometric measurements. The study of anthropometric fea- tures is associated with sports typology. It informs about the state of physical development and the ergonomic anthropometric characteristics of the athletes. The anthropometric profile of athletes of a certain sport provides information about the specific morphological selection, as well as the impact of this sport on the measurements and body development of the athlete. We measured somatometric parameters: 
body height, body weight, chest volume, lower limb length, shoulders width, pelvis width, foot length (parameters 1-8). Body length (height straight) - measure the distance from the floor to the highest point of the head (vertex) in $\mathrm{cm}$ to the nearest $1 \mathrm{~mm}$ with a Martin-type metal anthropometer with a scale length of no less than 2.1 meters by the method of MARTIN. To measure the shoulder and pelvis width and foot length a spreading caliper with an accuracy of $0,5 \mathrm{~cm}$ was used. Chest volume and length of the lower limbs were measured to the nearest $0,1 \mathrm{~cm}$ with the Lufkin W606PM tape measure, which passes behind at the lower corner of the shoulders, and beneath the chest in front. Length of lower limb ("standing still") - measured by the distance from the back of the iliac anterior superior to the floor with precision up to $1 \mathrm{~mm}$. The body weight was measured with calibrated electronic weighing scale with a precision of $0,1 \mathrm{~kg}$. The measurement of the larger dimensions of the body is presented in a standing position. The body mass index (BMI) is a value derived from a person's weight and height. BMI is defined as body mass divided by squares of body height and is universally expressed in units of $\mathrm{kg} / \mathrm{m}^{2}$, resulting in weight in kilograms and height in meters.

With the help of instrumental methods, we researched on the explosive force of the lower limbs and the jumping efficiency (tests 9-13), for which we used the accelerometer equipment "BTS G-sensor". The equipment is a methodology for studying various parameters that can be realized and observed during a certain type of jump.

The BTS G-sensor is a wireless system consisting of a device that has a built-in three-dimensional accelerometer, gyroscope and magnetometer, which is connected wirelessly to a computer. Through them the device calculates and records any change in the position of the body of the examined person. The BTS G-sen- sor is easy to use. The sensor is placed around the athlete's waist, attached to an ergonomic belt that allows freedom of movement. The athlete can jump freely, change direction and run short distances. The sensor connects to the computer via Bluetooth at a distance up to 20 meters.

When the test is completed, an automatically generated report shows all recorded spatial-temporal parameters: strength and power; and allows comparison of experiments.

Jumping tests were performed to measure the following parameters: jump height $[\mathrm{cm}]$; maximum force $[\mathrm{kN}]$; maximum velocity $[\mathrm{m} / \mathrm{s}]$; takeoff speed $[\mathrm{m} / \mathrm{s}]$, calculated time $[\mathrm{s}]$ and acceleration $\left[\mathrm{m} / \mathrm{s}^{2}\right]$. All data were recorded in separate protocols for each competitor.

\section{Data analysis}

For analysis of the results we used mathematical-statistical methods: descriptive statistics, correlation analysis and comparative analysis using Student's T-criterion for dependent samples with statistical the software package IBM SPSS STATISTICS v22 and MS Office 2018.

A. Descriptive statistics - to establish the variability of the studied indicators:

Calculation of sample's mean $(\overline{\mathrm{X}})$. The mean of the variable $\mathrm{X}$ is defined by the equality: $\bar{X}=\frac{\sum X}{n}, \mathrm{n}$ is the number of studied objects.

Standard deviation $S$ - an indicator that is a function of all observed values of $X$ in the sample and carries the most complete information about the degree of scattering of $X$ in the sample.

Calculated by the formula: $S=\sqrt{\frac{\sum(X-\bar{X})}{n-1}}$.

Coefficient of variation $V$ - in percent, which characterizes the homogeneity of the studied population and is calculated by the formula: $V=\frac{S}{\bar{X}} \cdot 100(\%)$.

B. Correlation analysis is used to evaluate the strength of the relationship between quantitative variables. The analysis compares the correlation coefficients between one or more 
pairs of variables to establish statistical relationships between them.

C. Comparative analysis with Student's t-test - to accept or reject the null hypothesis, regarding the observed differences between the mean levels of the studied traits both between the two participating in the experiment (at the beginning and end of the period) and between the initial and final state of each of these aggregates.

\section{RESULTS AND DISCUSSION}

The descriptive statistics of the anthropo- metric indicators in the first and in the second measurement (Tables 2 and 3) gave us low values for the coefficients of variation, asymmetry and excess. The coefficient of variation of all indicators was up to $17 \%$, which is an indicator for a homogeneous sample and normal distribution of data from the sample. The established normal distribution gave us grounds to make a comparative analysis of the studied sample using Student's T-criterion for the dependent samples, due to the fact that the same contingents of the research individuals were compared.

Table 2. Descriptive statistics of the anthropometric variables - first measurement

\begin{tabular}{lcccccccc}
\hline Variables & & $\boldsymbol{S}$ & $\boldsymbol{V} \boldsymbol{\%}$ & $\boldsymbol{A s}$ & $\boldsymbol{E x}$ & Max & Min & Range \\
\hline Body height $[\mathrm{cm}]$ & 147.23 & 6.55 & 4.45 & 0.158 & -1.021 & 158.40 & 138.00 & 20.40 \\
Body weight $[\mathrm{kg}]$ & 37.38 & 6.02 & 16.11 & 0.509 & -0.741 & 47.80 & 28.40 & 19.40 \\
Chest vol. [cm] & 64.69 & 4.27 & 6.60 & 0.270 & -0.615 & 73.00 & 58.00 & 15.00 \\
Length of right 1. [cm] & 85.01 & 5.34 & 6.28 & 0.817 & -0.021 & 95.60 & 77.10 & 18.50 \\
Length of left 1. [cm] & 85.12 & 5.13 & 6.03 & 0.954 & 0.290 & 95.80 & 78.50 & 17.30 \\
Shoulder width [cm] & 32.94 & 2.04 & 6.19 & 0.253 & -0.968 & 36.50 & 29.50 & 7.00 \\
Pelvis width [cm] & 22.65 & 1.98 & 8.75 & 0.210 & 0.045 & 26.50 & 19.00 & 7.50 \\
Foot length [cm] & 22.50 & 1.33 & 5.93 & 0.760 & 0.207 & 25.50 & 20.50 & 5.00 \\
BMI $\left[\mathrm{kg} / \mathrm{m}^{2}\right]$ & 17.17 & 1.87 & 10.90 & 0.533 & 0.136 & 21.31 & 14.15 & 7.16 \\
\hline
\end{tabular}

Table 3. Descriptive statistics of the anthropometric variables - second measurement

\begin{tabular}{lcccccccc}
\hline Variables & & $\boldsymbol{S}$ & $\boldsymbol{V} \%$ & $\boldsymbol{A s}$ & $\boldsymbol{E x}$ & Max & Min & Range \\
\hline Body height [cm] & 155.66 & 6.11 & 3.92 & -0.428 & -1.353 & 163.40 & 146.00 & 17.40 \\
Body weight [kg] & 46.26 & 7.89 & 17.05 & 0.838 & -0.206 & 64.00 & 37.50 & 26.50 \\
Chest vol. [cm] & 69.44 & 4.16 & 5.99 & 1.289 & 2.657 & 81.00 & 64.00 & 17.00 \\
Length of right 1. & 90.20 & 4.59 & 5.09 & -0.286 & -0.588 & 97.20 & 81.00 & 16.20 \\
[cm] & & & & & & & & \\
Length of left 1. [cm] & 89.75 & 4.34 & 4.83 & -0.101 & -0.347 & 97.20 & 81.50 & 15.70 \\
Shoulder width [cm] & 35.47 & 2.31 & 6.51 & 0.012 & -1.185 & 39.00 & 31.50 & 7.50 \\
Pelvis width [cm] & 23.74 & 1.96 & 8.26 & 0.444 & -0.141 & 28.00 & 20.50 & 7.50 \\
Foot length [cm] & 23.35 & 1.07 & 4.59 & 0.261 & -0.831 & 25.50 & 22.00 & 3.50 \\
BMI [kg/m $\left.{ }^{2}\right]$ & 19.01 & 2.40 & 12.63 & 1.096 & 1.664 & 25.25 & 15.34 & 9.91 \\
\hline
\end{tabular}

All anthropometric data from the first and The highest growth was in height, weight and second measurement are shown in Figure 1, length of the lower limbs, and the lowest - in where we can clearly see an increase in all the width of the pelvis, foot length and body factors, which is normal for adolescent girls. mass index. 


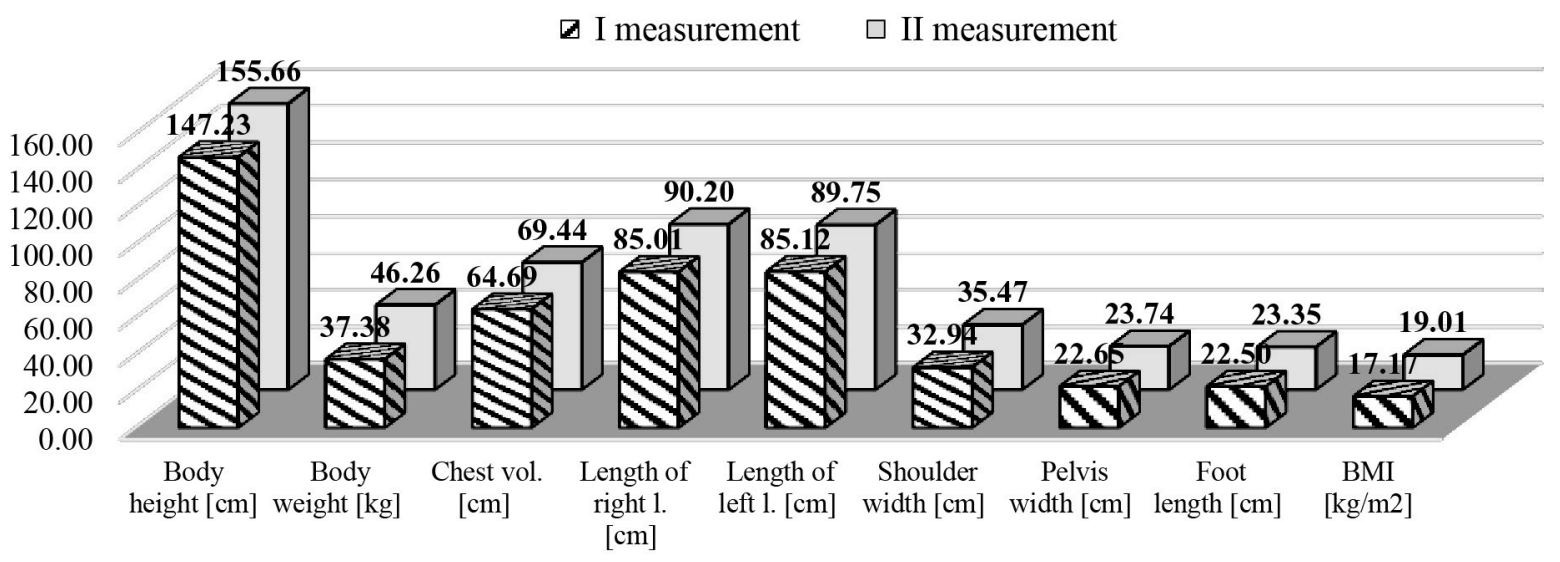

Figure 1. Dynamics of anthropometric variables

The empirical value of Student's T-test exceeded the table-identified critical levels (Table 4). An additional circumstance is the fact that the guaranteed probability $\mathrm{P}_{\mathrm{t}}[\%]$ exceeded the critical $(95 \%)$ value. Thus, with confidence, we should reject the null hypothesis and accept the alternative for the presence of a significant increase in data from the test sam- ple, relating to the growth in the anthropometric variables. The data from the initial and final measurement of the anthropometric indicators are presented in Table 4, as well as the absolute value of the increment and its percentage equivalent. For clarity of the same line, the calculated Student's T-distribution and the guarantee probability $\mathrm{P}_{\mathrm{t}}$ as shown.

Table 4. Comparative analysis of the anthropometric variables

\begin{tabular}{lcccccc}
\hline \multicolumn{1}{c}{ Variables } & I meas. & II meas. & d & d [\%] & t & Pt [\%] \\
\hline Body height [cm] & 147.23 & 155.66 & 8.43 & 5.73 & -10.35 & 100 \\
Body weight [kg] & 37.38 & 46.26 & 8.88 & 23.76 & -9.53 & 100 \\
Chest vol. [cm] & 64.69 & 69.44 & 4.75 & 7.34 & -9.91 & 100 \\
Length right leg [cm] & 85.01 & 90.20 & 5.19 & 6.11 & -7.55 & 100 \\
Length left leg [cm] & 85.12 & 89.75 & 4.63 & 5.44 & -6.83 & 100 \\
Shoulder width [cm] & 32.94 & 35.47 & 2.53 & 7.68 & -9.16 & 100 \\
Pelvis width [cm] & 22.65 & 23.74 & 1.09 & 4.81 & -4.05 & 99.91 \\
Foot length [cm] & 22.50 & 23.35 & 0.85 & 3.78 & -5.36 & 99.99 \\
BMI [kg/m ${ }^{2}$ ] & 17.17 & 19.01 & 1.84 & 10.72 & -5.92 & 100 \\
\hline
\end{tabular}

The movements of the figure skating athletes are spatial and are performed in two-support and one-support skating, as well as non-support (when performing jumps) and depend on both the dynamic parameters of the movement and the anthropometric parameters of the athlete (Vinogradova, 2013). In forecasting and orientation, it is necessary to understand the requirements of a sport to the quality characteristics of the athlete and how to change the indicators and proportions of body height and body weight, as well as physical qualities under the influence of growth and training. According to several authors - M. Matte, V. M. Zatsiorski and L. N. Sergienko, the most conservative are the peculiarities of the physique and speed-power qualities. The practice of figure skating suggests that among many dynamic and anthropometric 
parameters that affect the angular velocity $\omega$ in arc gliding, the most significant are the grouping of the skater by retracting the arms and legs to the body. Research conducted by V. Vinogradova shows that maintaining balanced skating is better for skaters with a conical body shape. To create the initial rotation in the jumps, the cylindrical shape of the body is preferable. In the cylindrical shape of the body, the angular velocity $\omega$ of the equilibrium sliding of the skater is higher. The conversion of this speed into a rotational speed when flying around its longitudinal axis increases the rotations of the jump.

The jumps in figure skating are an integral part of motor activity. One of the conditions for their good execution are great height and length. Criteria for this are speed-power qualities, the coordination capabilities and sustainability of the vestibular system. A study of differential development of speed-power capability, regarding takeoff found that among girls and junior girls the highest rate of development was observed at the ages between 10 and 14 years old (Volkov, 1981; Goncharov, 1952; Grodzitska, 1983, etc.). Several studies show that despite jumping being an innate ability of humans, by applying effective exercises one can significantly increase the level of speed-power readiness of the athletes (Verhoshanskiy, 2013). In biomechanical aspects, jumps represent an upward movement of the body relative to the support surface by means of the lower extremities followed by flight with rotation and landing.

According to biomechanics this movement is realized by the formula $\mathrm{h}_{\max }=\mathrm{V}_{\max } \cdot \mathrm{t}_{\text {takeoff }}$, where $\mathrm{h}_{\max }$ is the height of the jump, $\mathrm{V}_{\text {max }}$ is the maximum speed of the takeoff from the base, $\mathrm{at}_{\text {takeoff }}$ is the time that takes place through the bounce by the leg in concentric action of the extensor of the feet and also according to the law on the impulse of power

$$
\mathrm{F}_{\text {max }} \cdot \mathrm{t}_{\text {takeoff }}=m \cdot \mathrm{V}_{\text {max }} ; \mathrm{t}_{\text {takeoff }}=\frac{\mathrm{m} \cdot \mathrm{V}_{\max }}{\mathrm{F}_{\text {max }}} ; .
$$

If the athlete acquires linear speed by acceleration, in the event of a sudden stop it causes impact action and resistance from the base. The impact counteraction causes acceleration due to the reaction of the base. In the interaction, the law of conservation of momentum $\mathrm{m} \cdot \mathrm{V}_{1}=m \cdot \mathrm{V}_{2}$ applies. The weight of the athlete is marked with $m$. Thus, if there is no deformation of the body and the basing surface, the sliding speeds horizontally and the rebound vertically $\mathrm{V}_{1}=\mathrm{V}_{2}$. The abrupt stop reduces the speed $\mathrm{V}_{1}$ to 0 and if the amortization time $t_{a m}$ is small, acceleration occurs according to the formula $a_{a m}=\mathrm{V}_{1} / \mathrm{t}_{\text {am }}$ and $\mathrm{V}_{2}=a_{\text {takeoff }}$. $t_{\text {takeoff }}$

The inertia when stopping causes a reaction of the support and a deviation in the upward direction.

The height $\mathrm{h}_{\max }=\mathrm{V}^{2}{ }_{\max } / 2 . \mathrm{g}$;

$\mathrm{V}_{\text {max }}=\mathrm{F}_{\text {max }} \cdot \mathrm{t}_{\text {takeoff }} / \mathrm{m} ;$ Fmax $=\mathrm{m} \cdot \mathrm{V}_{\text {max }} / \mathrm{t}_{\text {takeoff }}$. Obviously, the maximum force occurs when the amortization time is short. Without force, there is no height $h_{\text {max }}$.

If the speed is $2 \mathrm{~m} / \mathrm{s}$, then the height becomes 0,2 meters, at $4 \mathrm{~m} / \mathrm{s}$ - the height is 0,8 $\mathrm{m}$, or it can be reached under ideal conditions. If the athlete adds extra strength during the push-up, it is added to the momentum of the reinforcement. Obviously, the damping and pushing times from the support must be as short as possible in the range of 0,1 or $0,2 \mathrm{sec}-$ onds. If we imagine that we apply force for a long interval, we lose the effect of the athlete's inertia. The force applied by the athlete must be for a short period of time to cause a cumulative effect on the inertia of movement. Weight $P=m . g$; the indicator $g$ is the value of the ground acceleration equal to $9,8 \mathrm{~m} / \mathrm{s}^{2}$. Thus, it is possible to determine what linear speed the athlete must acquire to reach a given height to perform the rotation. In the case of a curvilinear movement of a skier or skater along a trajectory, 
an inertial force of the centrifugal type arises, which gives great opportunities for changing the direction, because it facilitates the relief of skis or skates when reversing the direction of movement. The rotation is performed by itself. In the training of athletes, standards can be made defining mandatory requirements for speed or curvature of the sliding trajectory to achieve certain jumping indicators.
For the analyzes we consider the jump height $h$, the maximum force $F_{\max }$ during the realized motor activity, the maximum speed $V_{\max }$, the takeoff time $t_{\text {takeoff }}$ and the maximum acceleration $a_{\max }$.

The comparative analysis by Student's T-test for dependent samples of indicators at different jumps in the first and second measurement are presented in Table 5 .

Table 5. Comparative analysis of the biomechanics variables

\begin{tabular}{|c|c|c|c|c|c|c|}
\hline Variables & I meas. & II meas. & d & d [\%] & $\mathbf{t}$ & Pt [\%] \\
\hline $\mathrm{hSJ}[\mathrm{m}]$ & 0.34 & 0.38 & 0.04 & 11.76 & -3.59 & 99.75 \\
\hline FSJmax $[\mathrm{kN}]$ & 0.75 & 1.47 & 0.73 & 97.33 & -8.07 & 100.00 \\
\hline VSJmax $[\mathrm{m} / \mathrm{s}]$ & 2.11 & 2.59 & 0.48 & 22.75 & -6.19 & 100.00 \\
\hline tSJtakeoff [s] & 0.16 & 0.15 & -0.02 & -12.50 & 5.89 & 100.00 \\
\hline $\mathrm{aSJ}\left[\mathrm{m} / \mathrm{s}^{2}\right]$ & 13.00 & 17.75 & 4.75 & 36.54 & -7.11 & 100.00 \\
\hline $\mathrm{hCMJ}[\mathrm{m}]$ & 0.37 & 0.39 & 0.02 & 5.41 & -2.22 & 95.88 \\
\hline FCMJmax [kN] & 0.72 & 1.40 & 0.68 & 94.44 & -6.04 & 100.00 \\
\hline VCMJmax $[\mathrm{m} / \mathrm{s}]$ & 2.12 & 2.59 & 0.47 & 22.17 & -5.45 & 99.99 \\
\hline tCMJtakeoff [s] & 0.17 & 0.15 & -0.02 & -11.76 & 5.02 & 99.99 \\
\hline $\mathrm{aCMJ}\left[\mathrm{m} / \mathrm{s}^{2}\right]$ & 12.43 & 17.51 & 5.08 & 40.87 & -6.19 & 100.00 \\
\hline hCMJA [m] & 0.42 & 0.49 & 0.06 & 14.29 & -4.70 & 99.98 \\
\hline FCMJAmax $[\mathrm{kN}]$ & 1.18 & 2.12 & 0.94 & 79.66 & -4.19 & 99.93 \\
\hline VCMJAmax $[\mathrm{m} / \mathrm{s}]$ & 2.40 & 2.96 & 0.56 & 23.33 & -6.01 & 100.00 \\
\hline tCMJAtakeoff [s] & 0.18 & 0.17 & -0.01 & -5.56 & 2.18 & 95.55 \\
\hline $\operatorname{aCMJA}\left[\mathrm{m} / \mathrm{s}^{2}\right]$ & 13.64 & 18.16 & 4.52 & 33.14 & -4.64 & 99.97 \\
\hline $\mathrm{hDJ}[\mathrm{m}]$ & 0.29 & 0.40 & 0.11 & 37.93 & -3.91 & 99.88 \\
\hline FDJmax [kN] & 0.62 & 1.51 & 0.89 & 143.55 & -4.82 & 99.98 \\
\hline VDJmax $[\mathrm{m} / \mathrm{s}]$ & 1.70 & 2.72 & 1.01 & 59.41 & -6.65 & 100.00 \\
\hline tDJtakeoff [s] & 0.17 & 0.15 & -0.02 & -11.76 & 4.66 & 99.97 \\
\hline $\mathrm{aDJ}\left[\mathrm{m} / \mathrm{s}^{2}\right]$ & 10.01 & 18.35 & 8.33 & 83.22 & -8.74 & 100.00 \\
\hline $\mathrm{hRCMJ}[\mathrm{cm}]$ & 0.33 & 0.37 & 0.03 & 9.09 & -3.80 & 99.84 \\
\hline FRCMJmax [kN] & 0.72 & 1.08 & 0.36 & 50.00 & -4.23 & 99.94 \\
\hline VRCMJmax $[\mathrm{m} / \mathrm{s}]$ & 2.05 & 2.41 & 0.36 & 17.56 & -7.23 & 100.00 \\
\hline tRCMJtakeoff [s] & 0.16 & 0.15 & -0.01 & -6.25 & 2.29 & 96.40 \\
\hline $\mathrm{aRCMJ}\left[\mathrm{m} / \mathrm{s}^{2}\right]$ & 12.81 & 16.14 & 3.32 & 25.92 & -5.51 & 100.00 \\
\hline
\end{tabular}

SJ-Squat Jump, CMJ-Counter Movement Jump, CMJA-Counter Movement Jump with Arms, DJ - Drop Jump, RCMJ-Repeated Counter Movement Jump.

There was an increase in all indicators, be- bound force for all types of tested jumps, reaching especially significant at the maximum re- ing $143.55 \%$ in the Drop Jump (Figure 2). 


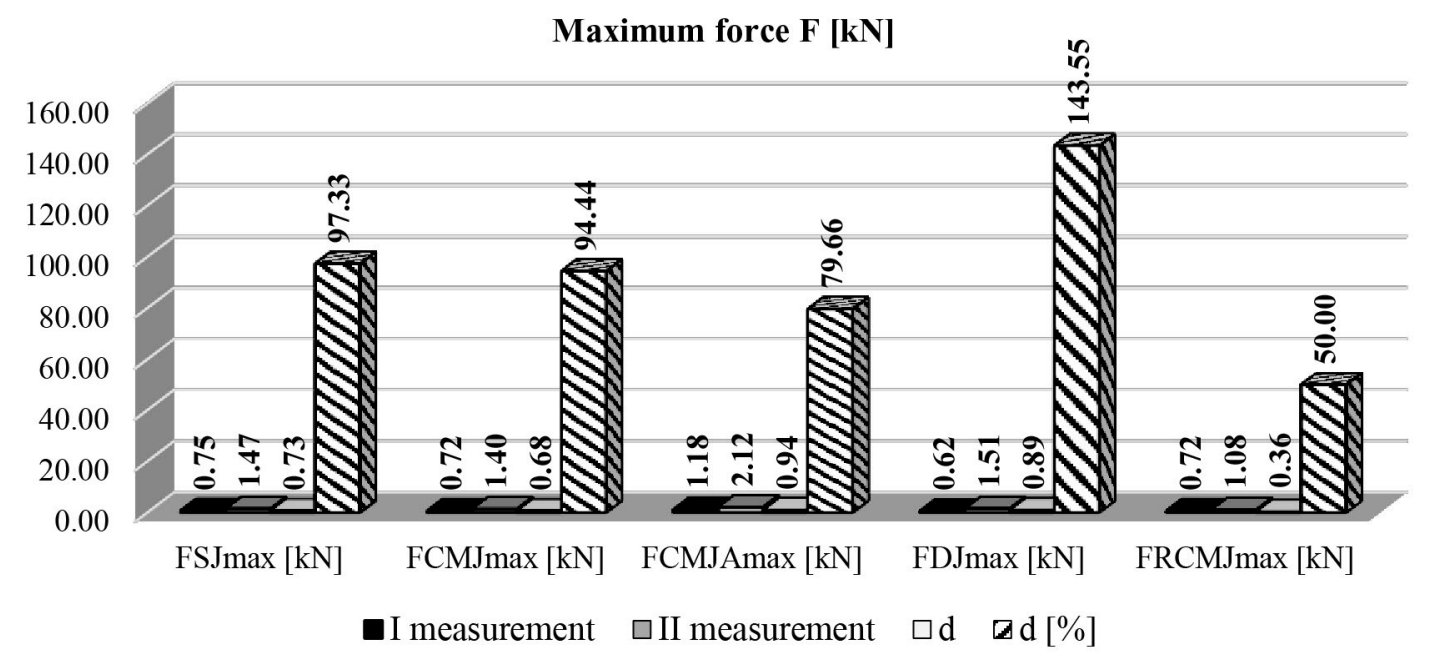

Figure 2. Growth of maximum force at different jumps

The increase in the reported rebound height into depth, followed by a rebound, of the abiliin drop jump (Figure 3) was higher compared ty to perform combinations of jumps, where it to other types of jumps $-37.93 \%$, which is due is important to maintain the momentum of the to the specific abilities of skaters to perform first jump. jumps with good amortization when stepping

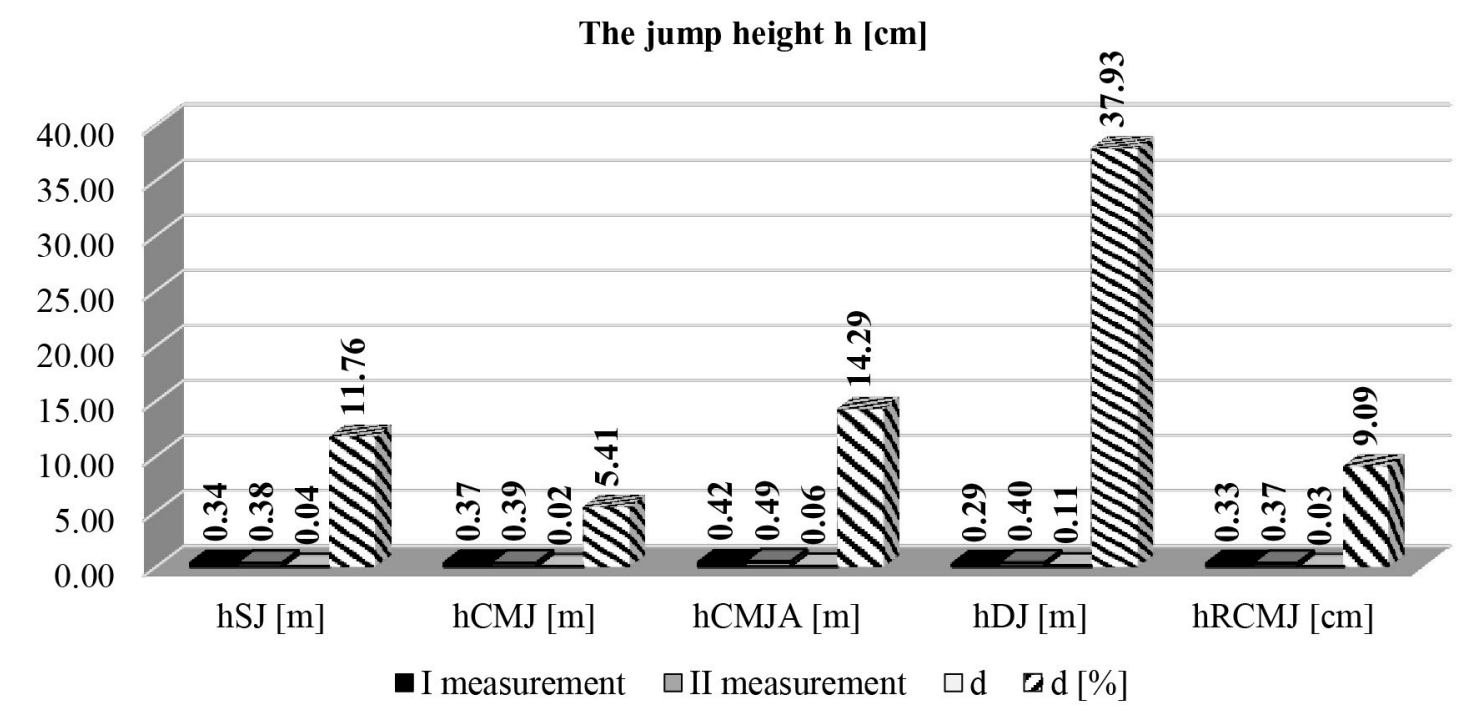

Figure 3. The jump height

In second place for the height of the jump $-\quad-$ VDJmax $=59.41 \%$ (Figure 4). There was $14.29 \%$ was a jump with the help of the hands, a large increase in acceleration in all jumps which is an indicator of good coordination of and especially in the rebound after falling into the competitors. The increase in maximum depth $-83.22 \%$. The repulsion time was negspeed was also the highest in drop jump DJ ative. 


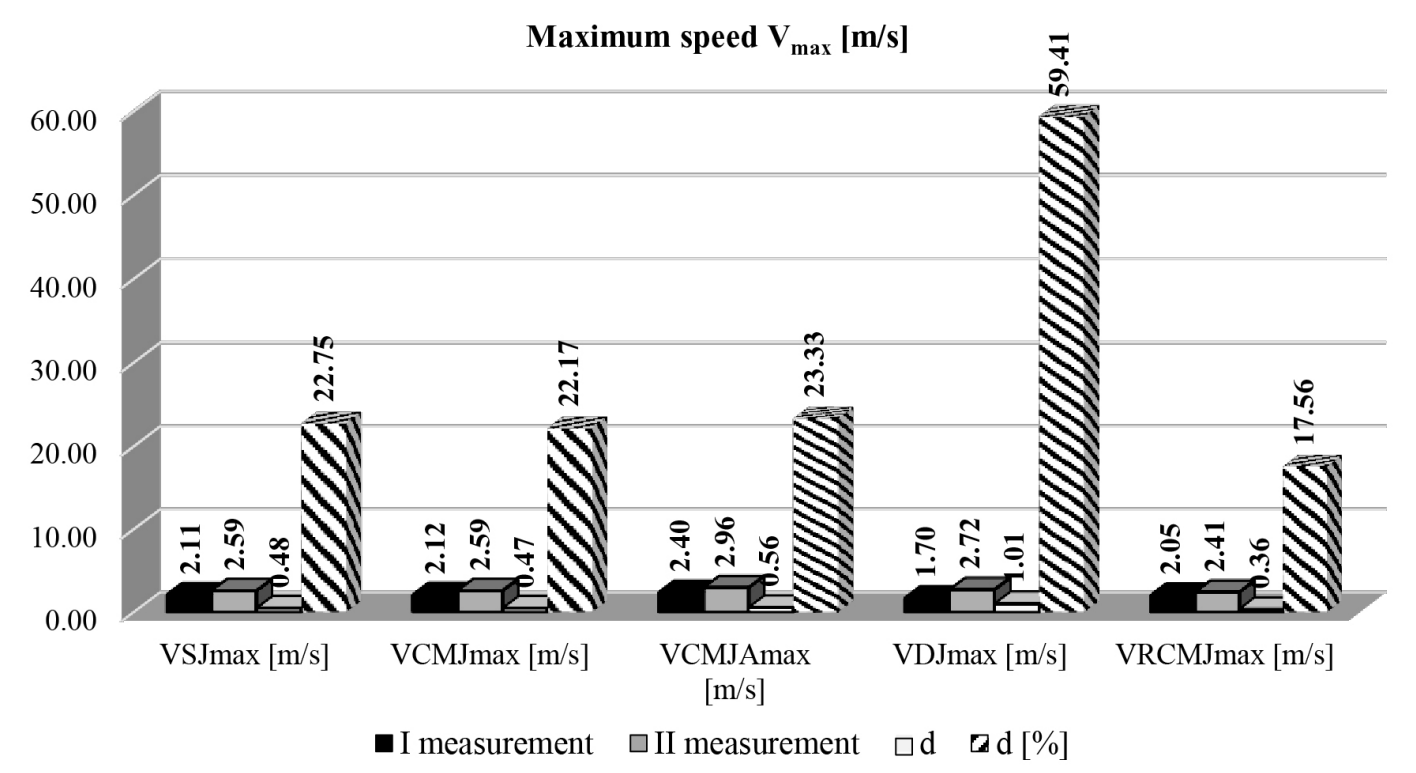

Figure 4. The maximum speed

The correlation analysis in the two measurements (Tables 6 and 7) of the indicators from the studied sample includes analysis by Pearson's multiple correlation. The indicators can be divided into two groups. One of them groups the results of anthropometric measurements, and the second forms the biomechanical variables, composed of kinematic and dynamic indicators. Intragroup correlation coefficients for anthropometric indicators in the first measurement are significant in nature - for the example height / weight (.758), height / chest circumference (.672), height / length of right leg (.896), height / length of left leg (.911), height / width of the shoulders (.880), height / width of the pelvis (.607), height / length of the foot (.917). The significant correlation coefficients of body weight to chest circumference (.848), weight / width of the shoulders (.756), weight / width of the pelvis (.693), weight / length of the foot (.679), body weight / BMI (.846). Intra-group correlations are also present in the biomechanical characteristics of kinematic and dynamic type - jump height / maximum force hSJ / FSJmax (.528), jump height / maximum speed hSJ / VSJmax (.741), jump height / time hSJ / tSJ .534), maximum speed / acceleration VSJmax / aSJ (.826). The correlation coefficients quoted so far are positive and in nature express the proportional relationship between the indicators presented in the study. This circumstance means that as one of them grows, so will the other. Between time and acceleration tSJ / aSJ is obtained (-.688), a value which has a negative sign and certifies that an increase in one of them will lead to a decrease in the other. Intergroup significant correlation coefficients of interest for the study are height and force of the jump with the help of the arms depending on the width of the shoulders hCMJAmax (.638) and FCMJAmax (.582) and the length of the foot (.514 and .593), maximum speed depending from the length of the legs and the foot FCMJAmax (.594, .530 and .612). Dependencies in rebound of the drop jump have a negative sign to the width of the pelvis hDJ - -.588, FDJ - -.513, VDJ - -.633. When performing 20 jumps, there is a dependence of the height of the bounce to the height $r=$ .543 , to the length of the legs $r=.540$ and 
.513 , to the width of the shoulders $r=.661$ dence between the time and the width of the and the length of the foot $r=.592$. The time shoulders is significant $r=.723$.

depends on the same indicators, as the depen-

Table 6. Correlations between anthropometric and biomechanics indicators - I test

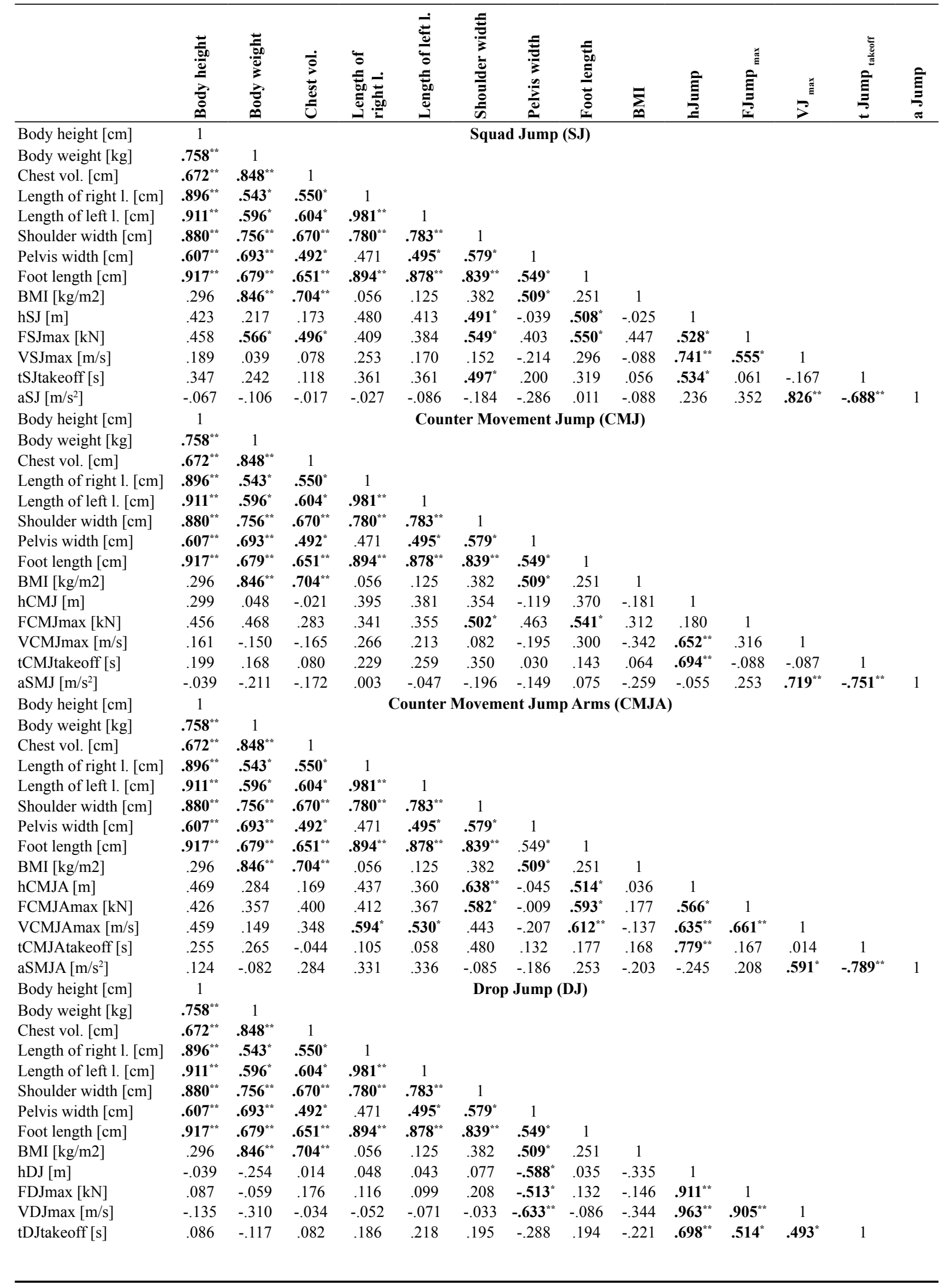




\begin{tabular}{|c|c|c|c|c|c|c|c|c|c|c|c|c|c|c|}
\hline $\mathrm{aDJ}\left[\mathrm{m} / \mathrm{s}^{2}\right]$ & -.226 & -.330 & -.083 & -.159 & -.194 & -.161 & $-.611^{\text {k* }}$ & -.211 & -.308 & $.804^{* * *}$ & $.798^{* *}$ & $.934^{* *}$ & .158 & 1 \\
\hline Body height $[\mathrm{cm}]$ & 1 & & & & eated $C$ & ounter & Moveme & ent Jum & p (RC) & & & & & \\
\hline Body weight $[\mathrm{kg}]$ & $.758^{* *}$ & 1 & & & & & & & & & & & & \\
\hline Chest vol. $[\mathrm{cm}]$ & $.672^{* * *}$ & $.848^{* *}$ & 1 & & & & & & & & & & & \\
\hline Length of right $1 .[\mathrm{cm}]$ & $.896^{* *}$ & $.543^{*}$ & $.550^{*}$ & 1 & & & & & & & & & & \\
\hline Length of left $1 .[\mathrm{cm}]$ & $.911^{* *}$ & $.596^{*}$ & $.604^{*}$ & $.981^{* *}$ & 1 & & & & & & & & & \\
\hline Shoulder width $[\mathrm{cm}]$ & $.880^{* *}$ & $.756^{* *}$ & $.670^{* *}$ & $.780^{* *}$ & $.783^{\text {** }}$ & 1 & & & & & & & & \\
\hline Pelvis width $[\mathrm{cm}]$ & $.607^{* *}$ & $.693^{\text {** }}$ & $.492^{*}$ & .471 & $.495^{*}$ & $.579^{*}$ & 1 & & & & & & & \\
\hline Foot length $[\mathrm{cm}]$ & $.917^{* *}$ & $.679^{* *}$ & $.651^{* *}$ & $.894^{* *}$ & $.878^{* *}$ & $.839^{* *}$ & $.549^{*}$ & 1 & & & & & & \\
\hline BMI $[\mathrm{kg} / \mathrm{m} 2]$ & .296 & $.846^{* *}$ & $.704^{* *}$ & .056 & .125 & .382 & $.509^{*}$ & .251 & 1 & & & & & \\
\hline $\mathrm{hRCMJ}[\mathrm{m}]$ & $.543^{*}$ & .381 & .279 & $.540^{*}$ & $.513^{*}$ & $.661^{* *}$ & .243 & $.592^{*}$ & .105 & 1 & & & & \\
\hline FRCMJmax [kN] & .319 & .419 & .405 & .245 & .225 & .421 & .367 & .364 & .355 & .320 & 1 & & & \\
\hline VRCMJmax $[\mathrm{m} / \mathrm{s}]$ & .206 & -.076 & .046 & .341 & .252 & .256 & -.203 & .316 & -.277 & $.703^{* * *}$ & .242 & 1 & & \\
\hline tRCMJtakeoff [s] & $.585^{*}$ & $.536^{*}$ & .332 & $.506^{*}$ & $.519^{*}$ & $.723^{* *}$ & .436 & $.574^{*}$ & .291 & $.926^{* *}$ & .287 & .386 & 1 & \\
\hline aRCMJ $\left[\mathrm{m} / \mathrm{s}^{2}\right]$ & -.458 & $-.604^{*}$ & -.314 & -.291 & -.362 & $-.584^{*}$ & $-.612^{* *}$ & -.391 & $-.491^{*}$ & $-.514^{*}$ & -.168 & .244 & $-.797^{\text {** }}$ & 1 \\
\hline
\end{tabular}

** Correlation is significant at the 0,01 level (2-tailed). * Correlation is significant at the 0,05 level (2-tailed). The critical values of the Pearson coefficient at $n=17: r_{0,05}=0.48$ and $r_{0,01}=0.61$

In the second measurement, Pearson's in- the height of all jumps depends on the width tragroup coefficients for anthropometric indi- of the shoulders, the highest is the Pearson cocators were again significant in nature but are efficient $r=.644$ and .663 in the takeoff withslightly lower than in the first measurement. out the help of the arms and in 20 consecutive The intergroup significant correlation co- jumps. The maximum force is significantly efficients that are of interest for the study is dependent on all anthropometric indicators. the significant dependence of the maximum Only the width of the pelvis does not affect this strength of all types of jumps on the growth of indicator. Indicator of maximum speed when the athletes. There is a significant dependence jumping with the arms and after rebounding of strength on weight and chest volume in all from height to shoulder width, respectively jumps except semi-squat takeoff. Interestingly, $r=.535$ and .488 .

Table 7. Correlations between anthropometric and biomechanics indicators - II test

\begin{tabular}{|c|c|c|c|c|c|c|c|c|c|c|c|c|c|c|}
\hline & 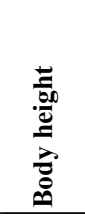 & 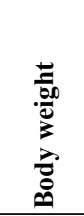 & 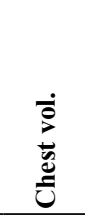 & 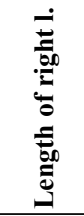 & 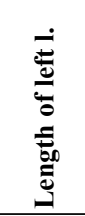 & 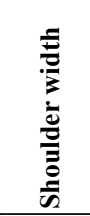 & 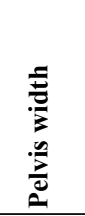 & 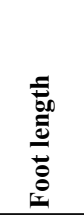 & $\sum_{\infty}^{E}$ & $\underset{\mathrm{g}}{\mathrm{g}}$ & 总 & $\vec{\lambda}^{\stackrel{m}{\Xi}}$ & 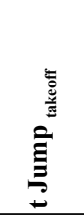 & $\underset{\tilde{\sigma}}{\stackrel{\hat{\Xi}}{E}}$ \\
\hline Body height [cm] & 1 & & & & & \multicolumn{3}{|c|}{ Squad Jump (SJ) } & & & & & & \\
\hline Body weight $[\mathrm{kg}]$ & $.686^{* *}$ & 1 & & & & & & & & & & & & \\
\hline Chest vol. [cm] & $.548^{*}$ & $.892^{* *}$ & 1 & & & & & & & & & & & \\
\hline Length of right $1 .[\mathrm{cm}]$ & $.860^{* *}$ & $.543^{*}$ & 440 & 1 & & & & & & & & & & \\
\hline Length of left $1 .[\mathrm{cm}]$ & $.865^{* *}$ & $.516^{*}$ & .413 & $.983^{* * *}$ & 1 & & & & & & & & & \\
\hline Shoulder width [cm] & $.733^{* *}$ & $.736^{* *}$ & $.621^{* *}$ & $.603^{*}$ & $.589^{*}$ & 1 & & & & & & & & \\
\hline Pelvis width [cm] & .463 & $.641^{* *}$ & .402 & .294 & .283 & .357 & 1 & & & & & & & \\
\hline Foot length [cm] & $.842^{* *}$ & $.659^{* *}$ & $.552^{*}$ & $.798^{* *}$ & $.777^{* *}$ & $.699^{* *}$ & .478 & 1 & & & & & & \\
\hline BMI [kg/m2] & .314 & $.9066^{* *}$ & $.844^{* *}$ & .201 & .162 & $.5^{3} 8^{*}$ & $.571^{*}$ & .365 & 1 & & & & & \\
\hline $\mathrm{hSJ}[\mathrm{m}]$ & .267 & -.031 & -.143 & .221 & .247 & $.546^{*}$ & -.229 & .283 & -.190 & 1 & & & & \\
\hline FSJmax $[\mathrm{kN}]$ & $.694^{* *}$ & .473 & .295 & $.542^{*}$ & $.575^{*}$ & $.731^{* *}$ & .250 & $.587^{*}$ & .214 & $.624^{* *}$ & 1 & & & \\
\hline VSJmax [m/s] & .275 & .012 & -.079 & .262 & .284 & .471 & -.260 & .244 & -.142 & $.881^{* *}$ & $.718^{* *}$ & 1 & & \\
\hline tSJtakeoff [s] & .083 & -.087 & -.183 & -.014 & .000 & .333 & .009 & .160 & -.154 & $.556^{*}$ & .078 & .101 & 1 & \\
\hline $\mathrm{aSJ}\left[\mathrm{m} / \mathrm{s}^{2}\right]$ & .226 & .074 & .032 & .256 & .269 & .258 & -.205 & .148 & -.037 & $.487^{\star}$ & $.623^{\text {** }}$ & $.842^{* *}$ & -.449 & 1 \\
\hline Body height $[\mathrm{cm}]$ & 1 & & & & \multicolumn{5}{|c|}{ Counter Movement Jump (CMJ) } & & & & & \\
\hline Body weight $[\mathrm{kg}]$ & $.686^{* *}$ & 1 & & & & & & & & & & & & \\
\hline Chest vol. [cm] & $.548^{*}$ & $.892^{* *}$ & 1 & & & & & & & & & & & \\
\hline Length of right $1 .[\mathrm{cm}]$ & $.860^{* *}$ & $.543^{*}$ & 440 & 1 & & & & & & & & & & \\
\hline Length of left $1 .[\mathrm{cm}]$ & $.865^{* *}$ & $.516^{*}$ & .413 & $.983^{* *}$ & 1 & & & & & & & & & \\
\hline Shoulder width $[\mathrm{cm}]$ & $.733^{* *}$ & $.736^{* *}$ & $.621^{* *}$ & $.603^{*}$ & $.589^{*}$ & 1 & & & & & & & & \\
\hline Pelvis width [cm] & .463 & $.641^{* *}$ & .402 & .294 & .283 & .357 & 1 & & & & & & & \\
\hline Foot length $[\mathrm{cm}]$ & $.842^{* * *}$ & $.659^{* *}$ & $.552^{*}$ & $.798^{* *}$ & $.777^{* *}$ & $.699^{\text {*k }}$ & .478 & 1 & & & & & & \\
\hline
\end{tabular}




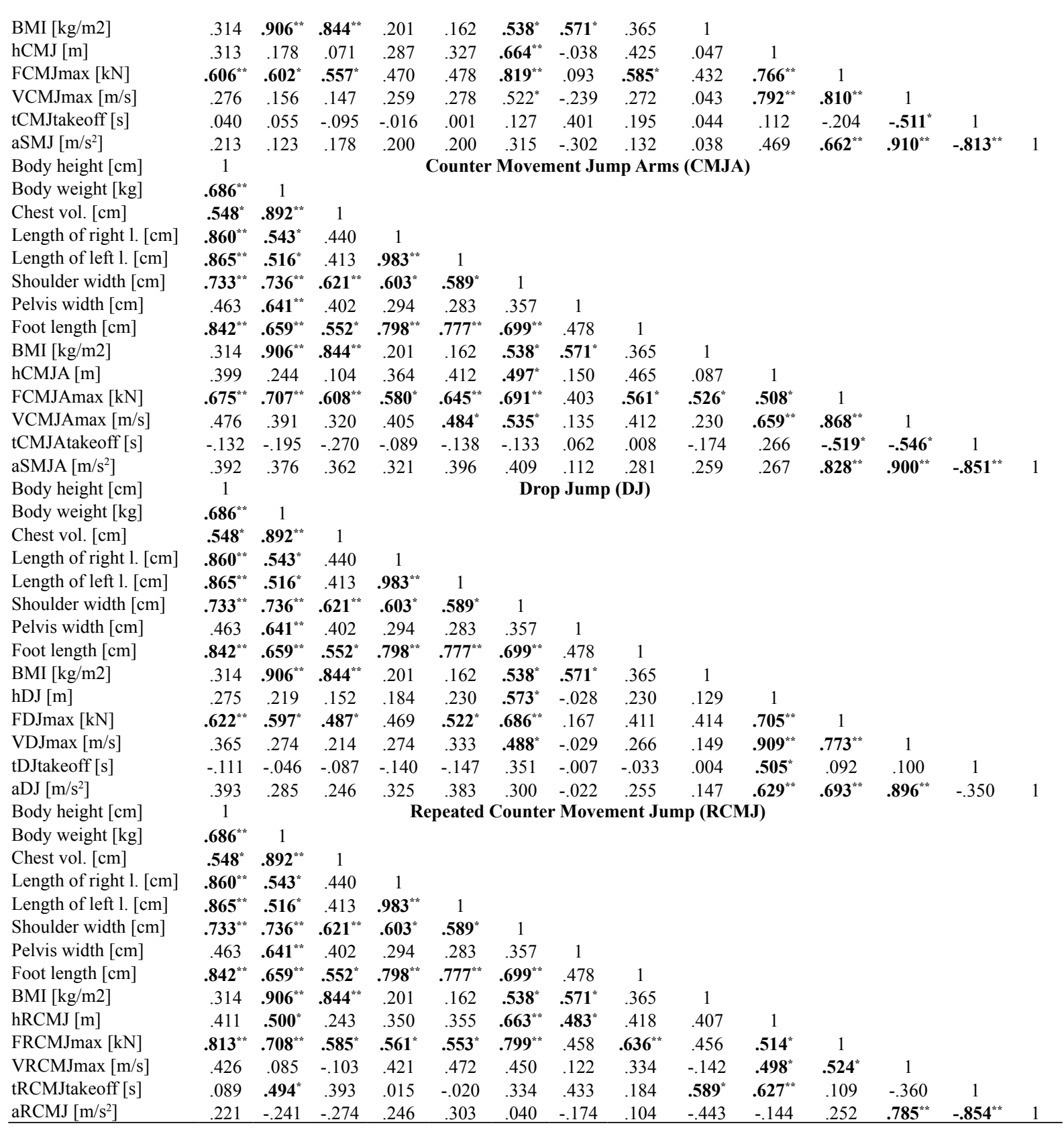

** Correlation is significant at the 01 level (2-tailed). * Correlation is significant at the .05 level (2-tailed). The critical values of the Pearson coefficient at $n=17: r_{0,05}=.48$ and $r_{0,01}=.61$

\section{CONCLUSION}

The analysis of the biomechanical characteristics of different types of jumping takeoff shows a significant increase in the maximum force, which allows to increase the height of the jumps. The increase in jump height in Drop Jump is the highest compared to other jumping indicators, which is probably due to the good amortization when stepping to a depth of 30 $\mathrm{cm}$, followed by a rebound, and the ability to perform combinations of jumps while maintaining the inertia of the first jump. In second place is the increase in height when jumping with the help of the arms, which is an indicator of good coordination, while the increase in maximum speed is highest in rebounding with prior amortization.

The increase in body mass index is very low in the second measurement compared to all other anthropometric indicators, which 
confirms the effect of training on body weight.

Significant intragroup dependences for the anthropometric and biomechanical indicators for all types of jumping takeoff were established and the decrease of the correlation coefficients was observed in the second measurement. At the same time, the maximum force in all types of jumps increases with increasing indicators of height, weight, length of the lower limbs, chest circumference, shoulder width, while the width of the pelvis does not affect the force of the takeoff. The height of the jump depends on the width of the shoulders. The dependence ranges from moderate $r=.497$ when jumping with the arms to significant $r=.664$ when jumping vertically with the hands on the hips. Pearson coefficients of intragroup biomechanical parameters range from significant force $r=.508$ to very strong $\mathrm{r}=.911$ between height and maximum jumping force.

We can make some pedagogical recommendations. The increase in sports results in figure skating requires the use of progressive teaching technologies to improve the technique of complex multi-rotational jumps. First of all, this implies knowledge of theories, rules that help to properly understand the complex kinematic and dynamic characteristics of movements. Having the basics of biomechanical analysis, a complex movement can be broken down into a number of its components and thus to understand its structure, to see the errors, to outline the prospects for the development of movement techniques, to select and define a set of special exercises aimed at mastering the technique of motor action, and to choose appropriate training methods. In figure skaters' jumps, swinging movements contribute to the movement of the General center of gravity of the body in the direction of takeoff, improve the coordination of movements during repulsion, provide a stable movement of the axis of rotation in flight phase, and increase the aesthetic impression of the jump. The movement of the free limbs and the skater's body during the jump change the magnitude of the base reaction. They are effective only when there is coordination of flexion and extension of the pushing leg. The coordinated execution of swinging movements and extension of the repulsive leg, the effective interaction of the skate with the ice make it possible to perform the required number of revolutions in flight with a stable movement of the axis of rotation.

\section{REFERENCES}

Absalyamova, I. V., Savpstyanova, R. B., Sharonova, M. A. (2019). Morfologicheskie pokazateli figuristok 6-8 let. Fizicheskoe vospitanie i sportivnaya trenirovka. № 4 (30). // Абсалямова, И.В., Савостьянова, Е.Б., Шаронова, М.A. (2019). Морфологические показатели фигуристок 6-8 лет. Физическое воспитание и спортивная тренировка. 2019 № 4 (30).

American Academy of Pediatrics (AAP) (2000). Pediatrics. Volume 106 Issue: 1.

Verhoshanskiy, Yu. V. (2013). Osnovy spetsialynoy silovoy podgotovki v sporte. Sovetskiy sport. // Верхошанский, Ю.В. (2013). Основы специальной силовой подготовки в спорте. Москва, Советский спорт.

Vinogradova, V. I. (2013). Osnovi biomehaniki prizhkov v figurnom katanii, Sovetskiy sport, Moskva. // Виноградова, В. И. (2013). Основы биомеханики прыжков в фигурном катании, Советский спорт, Москва.

Volkov, L. V. (1981). Fizicheskie sposobnosti detey i podrostkov. Kiev. // Волков, Л. В. (1981). Физические способности детей $u$ подростков. Киев.

Goncharov, N. N. (1952). Dinamika myshechnyh sokrashcheniy pri predelnyh napryazheniyah i ee vozrastnye izmeneniya: Avtoreferat dissertatsii kand. ped. Nauk, Moskva. // Гончаров, Н. Н. (1952). Динамика 
мышечных сокращений при предельных напряжениях и ее возрастные изменения: Автореф. дисс. канд. пед. наук. Москва, 1952.

Grodzitska, A. (1983). Skorostno-silovaya podgotovka yunyh figuristow. Avtoreferat dissertatsii, Moskva. // Гродзицка, А. (1983). Скоростно-силовая подготовка юных фигуристов. Автореферат диссертации, Москва.

Durakovic, M.M.(2012).Anthropometryin premenarcheal female esthetic sports athletes and ballerinas. Handbook of Anthropometry.

Zatsiorskiy, V. M., Sergienko, L. P. (1975). Vliyanie nasledstvennosti i stedy na razvitie dvigatelnyh kachestv cheloveka. Teotiya i praktika fizicheskoy kultury. Moskva. // Зациорский, В. М., Сергиенко, Л. П. (1975). Влияние наследственности и среды на развитие двигательных качеств человека. Теория и практика физической культуры. Москва.

Layzan, K. D., Gorskaya, I. Yu. (2016). Vzaimosvyaz orfofunktsionalnyh pokazateley s parametrami sportivnoy rezultativnosti figuristok-odinochnits 11-12 let. Omskiy nauchnyy vestnik. Seriya "Obshchestvo, istoriya, sovremennost” № 2. // Лайзан, К. Д., Горская, И. Ю. (2016). Взаимосвязь морфофункциональных показателей с параметрами спортивной результативности фигуристок-одиночниц 11-12 лет. Омский научный вестник. Серия „Общество, история, современность“" №2.

Lysova, I. A. (1977). Kolichestvennye harakteristiki, kriterii otsenki i puti optimizatsii proizvolnyh program figuristov-odinochnikov. Dissertatsiya kand. ped. nauk, Malahovka. // Лысова, И.А. (1977). Количественные характеристики, критерии оценки и пути оптимизации произвольных программ фигуристов-одиночников: Дисс. канд. пед. наук. Малаховка.

Martynenko, I. V., Borisenkova, E. S. (2019). Vliyanie veso-rostovyh pokazateley na sorevnovatelnuyu nadezhnost figuristokodinochnits pri ispolnenii pryzhkovyh elementov. Pedagogiko-psihologicheskie i medikobiologocheskie problem fizicheskoy kultury i sporta. 14(3): 12-18. DOI: 10.14526/20704798-2019-10-16. // Мартыненко, И. В., Борисенкова, Е. С. (2019). Влияние весо-ростовых показателей на соревновательную надежность фигуристокодиночниц при исполнении прыжжковых элементов. Педагогико-психологические и медико-биологические проблемы физической культуры и спорта. 14(3): 12-18. DOI: 10.14526/2070-4798-2019-10-16.

Mishin, A. N., Shapiro, V. A. (2014). Figurnoe katanie kak kosmicheskiy polet. Renome, Sankt-Peterburg. // Мишин, A. H., Шапиро, В. А. (2014). Фигурное катание как космический полет. Ремоме, СанктПетербург.

Monsma, D. \& Malina, R. (2005). Anthropometry and somatotype of competitive female figure skaters 11-22 years. Variation by competitive level and discipline. J Sports Med Phys Fitness. 2005 Dec; 45(4):491-500.

Paluchowska, M. (2015). The role of intense physical activity in the formation of body shape - research based on female figure skaters. // Pom J Life Sci 2015, 61, 3, 310-314.

Porter E., Young C., Niedfeldt M., Gottschlich L. (2007). Sport-specific injuries and medician problems of figure skaters. Wis Med J. 2007, 106 (6), 330-334.

Sergienko, L. P. (1980). Polovye osobennosti vliyaniya nasledstvennosti i sredy na razvitie dvigatelnyh kachestv cheloveka. Teoriya i praktika fizicheskoy kultury, № 3. // Сергиенко, Л. П. (1980). Половые особенности влияния наследственности и среды на развитие двигательных качеств человека. // Теория и практика физической культуры № 3.

Slater, G., O’Connor, H., Kerr, A., 
(2018). Optimizing Physique for Sports sporta. Sofia: NSA. // Тотева, M. (1992). Performance, Best Practice Protocols for Соматотипология в спорта. София: HCA.

Physique Assessment in Sport, ed: Patria A. Tucker, R., Collins, M., (2012). What Hume, Deborah A. Kerr, Timothy R. Ackland, makes champions? A Review of the Relative Springer Nature Singapore Pte Ltd., p. 27-36. Contribution of Genes and Training to Sporting Toteva. M. (1992). Somatotipologiya v Success. Br J Sports Med., 46:555- 561.

\section{Corresponding author:}

Tatiana Yordanova

Technical and Ice Sports department National Sports Academy "Vassil Levski"

21, Acad. Stefan Mladenov str.Sofia 1700, Bulgaria

E-mail: tania.yordanova@online.bg 